\title{
KONSEKWENCJE DEFINIOWANIA MYŚLI POLITYCZNEJ DLA KWESTIONARIUSZA BADAŃ POLITOLOGICZNYCH
}

\begin{abstract}
W artykule omówiono konsekwencje zmodernizowania definicji myśli politycznej dla kwestionariusza badań politologicznych. W latach osiemdziesiątych i dziewięćdziesiątych XX w. myśl polityczna była definiowana jako refleksja o polityce, natomiast rozwój tożsamości naukowej politologii wymusił używanie w procesie definiowania kategorii rzeczywistość polityczna, czyli powiązanie pojęcia „myśl polityczna” z określeniami polityczność i polityzacja. Z dokonanej analizy wynika, że zasadnicze zmiany w definiowaniu myśli politycznej, jakie dokonały się w pierwszej dekadzie XXI w., generują potrzebę wyznaczania nowych zadań badawczych dla politologów - badaczy myśli politycznej. Nowe wyzwania (powinności) pojawiły się dla politologów w odniesieniu do trzech potrzeb poznawczych. Są to: 1) badanie poglądów podmiotów politycznych na polityczność i politykę; 2) rozszerzenie bazy źródłowej o ślady myśli politycznej; 3) dokonanie standaryzacji badań politologicznych realizowanych $\mathrm{w}$ tej subdyscyplinie. $\mathrm{W}$ artykule wskazano na dwa typy źródeł $\mathrm{w}$ badaniach politologicznych myśli politycznej - świadectwa i ślady myśli politycznej oraz zaproponowano trzy, połączone ze sobą kwestionariusze badawcze - uniwersalny, historyczny i specjalny.

Słowa kluczowe: myśl polityczna, metodologia politologii, teoria polityki.
\end{abstract}

\section{WPROWADZENIE}

Politologia potrzebuje tożsamości naukowej, która pozwoliłaby na wykreślenie granic jej odrębności od innych nauk humanistycznych i społecznych². Podstawowym składnikiem każdej dyscypliny naukowej jest klarowne zdefiniowanie przedmiotu badan, jednak większość poszukiwań w ostatniej dekadzie XX stulecia pomijała ten wymóg i koncentrowała się wokół recypowania do nauki w Polsce rozwiązań teoretycznych (tzw. paradygmaty badań) z państw, gdzie badania politologiczne w przeszłości nie były

\footnotetext{
${ }^{1}$ Dr hab. prof. UMCS, Waldemar Paruch, Wydział Politologii, UMCS, Pl. Litewski 3, 20-080 Lublin, tel.: 815265 146, e-mail: wparuch@o2.pl

2 Odmiennie podejście do kwestii tożsamości naukowej politologii zaprezentowali autorzy opublikowanych ostatnio monografii: Barbara Krauz-Mozer i Paweł Ścigaj (redaktorzy) i Ryszard Skarzyński (autor i redaktor): B. Krauz-Mozer, P. Ścigaj, Sklep z podróbkami? Podejścia badawcze $i$ metodologie $w$ nauce o polityce, [w:] Podejścia badawcze i metodologiczne $w$ nauce o polityce, red. B. Krauz-Mozer, P. Ścigaj, Kraków 2013, s. 9-30; R. Skarzyński, Podstawowy dylemat politologii: Dyscyplina nauki czy potoczna wiedza o spoteczeństwie? O tradycji uniwersytetu $i$ demarkacji wiedzy, Białystok 2012, s. 25-104; idem, Podstawowy dylemat politologii I (2010), [w:] Przedmiot poznania politologii: Podstawy dyscypliny nauki, red. R. Skarzyński, Białystok 2014, s. $77-88$.
} 
bezpośrednio zdeterminowane przez system polityczny. W konsekwencji powstało zjawisko błądzenia ontologicznego i epistemologicznego, którego efektem było przeświadczenie, że poszukiwanie odrębności politologii na podstawie przedmiotu badań wydaje się nieskuteczne ${ }^{3}$. Zdecydowanie bliższe jest nam przekonanie inne, że wyznaczanie granic politologii jest ,zrozumiałym i oczywistym przejawem dojrzewania każdej nauki" ". Pisano w ważnych opracowaniach naukowych o politologii empirycznej, teoretycznej, behawioralnej, postmodernistycznej i ideologicznej lub wracano do pojęć „nauka o polityce”/,nauki o polityce”/,nauki polityczne”. Warto wymienić chociażby publikacje: Barbary Krauz-Mozer, Władysława Szostaka, Ziemowita Jacka Pietrasia i Tadeusza Klementewicza ${ }^{5}$

Przywołane uwagi odnoszą się nie tylko do politologii jako dyscypliny naukowej, ale również do jej podstawowych subdyscyplin. Jedną z nich jest myśl polityczna - oprócz systemów politycznych, stosunków międzynarodowych, ruchów i partii politycznych, teorii polityki, polityki szczegółowej różnego typu. Wymienione pojęcia oznaczają z jednej strony subdyscyplinę politologii, $\mathrm{Z}$ drugiej zaś kategorię podstawowa dla politologii. W każdej z wymienionych subdyscyplin starano się: 1) zdefiniować przedmiot poznania; 2) opracować strukturę pojęciową; 3) wyznaczyć podstawowe założenia metodologiczne; 4) sformułować katalog celów/oczekiwań badawczych ${ }^{6}$. Na gruncie wymienionych subdyscyplin powstała dość zastanawiająca sytuacja: w odróżnieniu od politologii, zasadniczo nie pisano o braku możliwości określenia przedmiotu badań, lecz koncentrowano uwagę na rozstrzyganiu konkretnych dylematów poznawczych.

W latach 1975-1976 dwaj badacze - Henryk Zieliński i Marek Sobolewski sformułowali sugestie wyjątkowo inspirujące dla następnych pokoleń zorientowanych na poznawanie myśli politycznej. Pierwszy $\mathrm{z}$ nich wskazał na potrzebę badania myśli politycznej w ujęciu historycznym i politologicznym ${ }^{7}$, drugi zaś zasugerował rezygnację z definiowania myśli politycznej, uznając takie rozważania za nieprzynoszące pożytku ${ }^{8}$. O ile stosunkowo wcześnie, bo w 1985 r., Michał Jaskólski zanegował zasadność poglądu

\footnotetext{
${ }^{3}$ B. Krauz-Mozer, P. Ścigaj, op. cit., s. 14.

${ }^{4}$ J.H. Kołodziej, Wartości polityczne - problem badawczy dla politologa, [w:] Podejścia badawcze $i$ metodologiczne..., s. 199; podobne stanowisko w: R. Skarzyński, Monizm i pluralizm w rozwoju dyscypliny nauki: politologia i pseudopolitologia, [w:] Przedmiot poznania politologii..., s. 10.

5 Zob. B. Krauz-Mozer, W. Szostak, Teoria polityki: podstawy metodologiczne politologii empirycznej, Kraków 1993, passim; T. Klementewicz, Spór o model metodologiczny nauki o polityce, Warszawa 1991, passim; idem, Politologia tradycyjna a politologia teoretyczna $w$ poszukiwaniu modelu metodologicznego nauki o polityce, „Studia Polityczne” 1992/1, s. 95-106; Z.J. Pietraś, Teoria decyzji politycznych, Lublin 1990; idem, Politologia ideologiczna, behawioralna czy postmodernistyczna, [w:] Politologia w szkolnictwie wyższym w Polsce, red. E. Olszewski, Lublin 1997, s. 39-48.

${ }^{6}$ Wykorzystano wnioski - S. Rittel, Zjawiska polityczne w ujęciu systemowym, „Zeszyty Naukowe Politechniki Krakowskiej. Nauki Ekonomiczne" 1989/21, s. 3.

${ }^{7}$ Zob. H. Zieliński, O potrzebie i trudnościach badania dziejów polskiej myśli politycznej, [w:] Polska myśl polityczna XIX i XX wieku, t. 1: Polska i jej sasiedzi, red. H. Zieliński, WrocławWarszawa-Kraków-Gdańsk 1975, s. 13-21.

8 Zob. M. Sobolewski, Niektóre problemy teorii $i$ metodologii historii doktryn politycznych, „Historyka” 1976/6, s. 3-17.
} 
Sobolewskiego ${ }^{9}$, o tyle w drugiej dekadzie XXI w., kiedy mija już niemal 40 lat od wezwania sformułowanego przez Zielińskiego, jest potrzebne jednoznaczne przejście w badaniach myśli politycznej od etapu preteoretycznego do kolejnej fazy wyodrębniania się tej subdyscypliny politologii.

W polskim piśmiennictwie naukowym jest odczuwalna potrzeba wypracowania (lub kodyfikacji) metodologii badań myśli politycznej, trudno bowiem zaakceptować stan, kiedy publikacje $\mathrm{z}$ zakresu tej subdyscypliny politologii w zasadniczej większości (w tym prace doktorskie, monografie habilitacyjne) przyjmują całkowicie dowolną postać konstrukcyjną, są pozbawione refleksji metodologiczno-teoretycznej, sprowadzają się do prostego i często niewiarygodnego ustalania poglądów na podstawie źródeł historycznych, nie stanowią krytycznej analizy materiału źródłowego ${ }^{10}$. Są to kwestie natury fundamentalnej, w których nie ma miejsca na błędnie pojmowany pluralizm naukowy, lecz jest konieczny monizm metodologiczny. Sytuacja w zakresie badania myśli politycznej jest o tyle lepsza od innych subdyscyplin politologii, że jej adepci nie zapominają o źródłach historycznych jako podstawie wszelkich ustaleń, ale coraz częściej analiza danych informacyjnych (faktów źródłowych) jest zastępowana przez bezkrytyczny opis lub przepisywanie fragmentów dokumentów programowych, niemal całkowicie bowiem wyeliminowano źródłoznawstwo $\mathrm{z}$ edukacji politologicznej, a kultura metodologiczna generalnie jest w upadku. Ta ostatnia uwaga odnosi się do wszystkich trzech działów metodologii: przedmiotowej, pragmatycznej i apragmatycznej.

Zaplanowane i zorganizowane w wadliwy sposób badania prowadzą do formułowania błędnych wniosków, na przykład w odniesieniu do klasyfikacji partii politycznych z wykorzystaniem pojęć lewica, prawica i centrum oraz mnożenia określeń, które zamiast ułatwiać zrozumienie rzeczywistości politycznej, faktycznie prowadzą do jej zaciemnienia. Przykładem niech będą określenia z różnego porządku analizy, na przykład koncepcje programowe i partia protestu. Określenie koncepcje programowe jest w zasadniczej sprzeczności w zestawieniu z rozważaniami metodologicznymi z zakresu myśli politycznej. Przecież na myśl polityczną składają się: teorie naukowe wykorzystywane przez podmioty polityczne, ideologie, koncepcje i programy. Trudno także określić zawartość ideologiczno-programową podmiotu politycznego nazwanego partią protestu.

Porządkowanie podstaw metodologiczno-teoretycznych badań myśli politycznej wymaga oczywiście poszanowania wolności nauki, ale powinno się opierać na czterech kotwicach.

Pierwszą jest definicja myśli politycznej. Bez obowiązkowych ustaleń w tej kwestii trudno wyobrazić sobie komunikację nie tylko w środowisku uczonych, ale również między uczonymi a politykami, gdyż politologia jest nauką stosowaną. Ta świadomość jest wyjątkowo ważna w warunkach oczekiwania od nauki możliwości aplikacyjnych. Wraz z rozwojem metodologii badań politologicznych istotnej modernizacji wymagała, pozbawiona uzależnień ideologicznych, definicja myśli politycznej wypracowana przez środowisko akademickie w latach dziewięćdziesiątych XX w. Począwszy od Andrzeja Zybertowicza, który w 1990 r. pisał, że myśl polityczna to wszelka wyartykułowana

\footnotetext{
${ }^{9}$ M. Jaskólski, Szkice o historii doktryn politycznych i prawnych, Warszawa-Kraków 1985, s. 20 21.

${ }_{10}$ Przykładem może być publikacja: Z. Nowakowski, Bezpieczeństwo państwa $w$ koncepcjach programowych partii parlamentarnych w Polsce po 1989 roku, Warszawa 2009.
} 
wypowiedź „dotycząca sfery polityki”, a skończywszy na wypowiedzi z 1999 r. autora niniejszego artykułu, że myśl polityczna to „wszelka forma refleksji nad polityką"11. W naszej opinii ugruntowanej w latach 2005-2009 należy zrezygnować w definiowaniu myśli politycznej z odwołania się do kategorii polityka, lecz uczynić przedmiotem odniesienia myśli politycznej rzeczywistość, a tym samym wskazać w definicji na zjawiska polityzacji i polityczności. Jest to logiczna konsekwencja uznania rzeczywistości politycznej za przedmiot poznania politologii i traktowania polityki jako jednego $\mathrm{z}$ licznych zjawisk politycznych ${ }^{12}$. Myśl polityczna jest wtedy zbiorem poglądów na temat rzeczywistości politycznej, niezależnie od stopnia ich rozwoju, wewnętrznej spójności i systematyzacji oraz teoretyzowania i konkretyzacji ${ }^{13}$. W tym kontekście $\mathrm{w}$ myśli politycznej priorytetową rolę odgrywają refleksje o: zaspokajaniu interesów za pomocą podejmowanych decyzji władczych; narzuceniu $w$ danym czasie $i \mathrm{w}$ konkretnej przestrzeni własnego ładu politycznego innym uczestnikom stosunków społecznych; przejęciu i utrzymaniu władzy w państwie przez podmiot tworzący myśl polityczną. Konsekwencją takiego rozumowania jest odrzucenie mniemania obecnego w piśmiennictwie naukowym, że myśl polityczną można ograniczyć jedynie do poglądów na temat polityki, zjawiska władzy oraz jej instytucji czy też ustroju państwa. Takie skojarzenia wynikały z lekceważenia lub negowania znaczenia takich zjawisk, jak polityczność i polityzacja. Zakres pojęcia myśl polityczna jest zdecydowanie szerszy, niż sądzono w rozważaniach teoretycznych w latach osiemdziesiątych i dziewięćdziesiątych XX w., polityczne bowiem mogą być - i najczęściej są - chociażby opisy rzeczywistości, wyjaśnienia i oceny wydarzeń oraz procesów, konstruowanie związków przyczynowoskutkowych, funkcjonalnych i strukturalnych.

Drugą kotwicą jest nadrzędność pojęcia „myśl polityczna” nad teorią polityczną, ideologią, koncepcją/doktryną i programem. Wymienione cztery pojęcia przejawiania się myśli politycznej (warstwy) nie muszą mieć postaci materialnej, lecz są obrazami mentalnymi, wygenerowanymi $\mathrm{w}$ wyniku procesu myślenia. Tym samym wszelkie badania doktryn politycznych i teorii politycznych są fragmentem refleksji o myśli politycznej, gdyż zakres tego pojęcia obejmuje rozważania o charakterze teoriopolitycznym, ideologicznym, koncepcyjno-doktrynalnym i programowym. Zostały więc negatywnie zweryfikowane dwa odmienne stanowiska. Pierwsze zaprezentował Franciszek Ryszka w reakcji na propozycję przedłożoną przez Henryka Zielińskiego, pisząc w 1976 r., że myśl polityczna jest stadium pośrednim między ideologią a programem, nazwą , dla pomysłów i poglądów, które jeszcze ideologią polityczną nie są,

11 A. Zybertowicz, Kategorie do badania polskiej myśli politycznej. (Rozważania wstępne), [w:] Studia z dziejów polskiej myśli politycznej, t. 2: Polska myśl polityczna w dzielnicy pruskiej w XIX wieku, red. S. Kalembka, Toruń 1990, s. 10; W. Paruch, Myśl polityczna - refleksje metodologiczne o pojęciu, „Annales Universitatis Mariae Curie-Skłodowska, Sectio K: Politologia” 1999/6, s. 36.

${ }_{12}$ Definicję polityczności przyjęto za Skarzyńskim: R. Skarzyński, Przedmiot poznania politologii, [w:] Przedmiot poznania politologii..., s. 238-243; odmienne stanowisko zob. A. Czajowski, Polityczność dziatań społecznych, [w:] Polityka i polityczność: Problemy teoretyczne $i$ metodologiczne, red. A. Czajowski, L. Sobkowiak, Wrocław 2012, s. 69-100.

${ }^{13}$ W. Paruch, Myśl polityczna obozu pitsudczykowskiego 1916-1939, Lublin 2005, s. 10; zob. idem, Myśl polityczna we wspótczesnej polskiej politologii: modernizacja przedmiotu, strategii i metody badań, [w:] Politologia w Polsce: Stan i perspektywy, red. M. Cichosz, K. Zamorska, Wrocław 2006, s. 207-214; J. Jachymek, W. Paruch, Wstęp, [w:] Więcej niż niepodległość: Polska myśl polityczna 1918-1939, red. J. Jachymek, W. Paruch, Lublin 2001, s. 11-12. 
ale są już więcej niż doraźnym programem [...]"14. Drugie stanowisko wyrażali niejednokrotnie tacy specjaliści, jak Henryk Zieliński, Adam Czarnota, Aleksander Łuczak, którzy wyłączyli z zakresu pojęcia „myśl polityczna” doktryny polityczne i polityczno-prawne, uznając je za przedmiot poznania odrębnej dyscypliny naukowej ${ }^{15}$.

Trzecim założeniem jest zróżnicowany poziom uporządkowania wewnętrznego myśli politycznej. Myśl polityczna może być koherentna oraz mająca wyraźnie widoczny rdzeń ideologiczny, ale w odniesieniu do innych egzemplifikacji historycznych przybiera postać albo rozważań jedynie fragmentarycznych, albo heretyckich rozwiązań ideologicznoprogramowych. Obowiązkiem badacza jest zaś analizowanie i wyjaśnianie każdej myśli politycznej, poszukiwanie racjonalności danego podmiotu politycznego prowadzącego działalność ideotwórczą i podejmującego decyzje polityczne, także o niewielkim stopniu uporządkowania.

Niejednokrotnie politolog, analizując myśl polityczną, formułuje sądy synoptyczne, obejmujące powiązania teoretyczne, kategorialne i konfiguralne, które nie były doświadczane przez podmiot polityczny ${ }^{16}$. Tym samym narracja politologiczna jest niejednokrotnie nasycona pojęciami nieużywanymi przez twórcę badanych idei. Twórca idei komunikuje się z ich odbiorcami, w tym z naukowcami, używając wymyślonych terminów (konstruktów) zaliczanych do języka polityki ${ }^{17}$. Te konstrukty powinny być poddane przez politologów krytyce i interpretacji zgodnie z kanonami źródłoznawstwa oraz neutralności poznawczej. Takie postępowanie jest mocno uzasadnione $\mathrm{z}$ trzech powodów.

Po pierwsze, politolog nie jest kronikarzem wybranego ugrupowania politycznego ani konkretnego polityka, lecz ma obowiązek dokonać krytyki języka źródeł za pomocą siatki pojęciowej właściwej dla badań politologicznych. Trudno sobie wyobrazić analizowanie komunistycznej myśli politycznej jedynie z wykorzystaniem sloganów propagandowych właściwych dla tej formacji takich jak „,dyktatura proletariatu” lub „ludowładztwo”. Jakże niezrozumiała byłaby monografia na temat myśli politycznej Lecha Wałęsy napisana przy użyciu pojęć stosowanych przez tego polityka, takich jak ,plusy dodatnie, plusy ujemne”, „,nie chcę, ale muszę”. Po drugie, badacz myśli politycznej powinien koncentrować swoją uwagę na dokonywaniu analizy kauzalno-nomologicznej, poszukiwaniu jednoznacznych związków typu przyczynowo-genetycznego oraz praw, prawidłowości, zależności synchronicznych i diachronicznych ${ }^{18}$. Opis nie jest ostatecznym efektem badań politologicznych myśli politycznej, od autora monografii na ten temat oczekuje się formułowania wyjaśnień, prognoz i predykatów, mimo że taką wiedzą nie dysponowali politycy na przykład ruchu ludowego na początku XX w. czy też Samoobrony RP w okresie III Rzeczypospolitej. Po trzecie, w analizach politologicznych należy przyjąć

${ }^{14}$ F. Ryszka, [rec. Polska myśl polityczna XIX i XX wieku, t. 1: Polska i jej sąsiedzi, red. H. Zieliński, Wrocław-Warszawa-Kraków-Gdańsk 1975], „Odra” 1976/5, s. 101.

${ }^{15}$ A. Czarnota, Problemy syntezy polskiej myśli politycznej - rozważania wstępne, [w:] Polska myśl polityczna XIX $i$ XX wieku, t. 7: Państwo w polskiej myśli politycznej, red. W. Wrzesiński, Wrocław-Warszawa-Kraków-Gdańsk-Łódź 1988, s. 271; H. Zieliński, op. cit., passim; A. Łuczak, Spoteczeństwo i państwo w myśli politycznej ruchu ludowego, Warszawa 1982, s. 6.

${ }^{16}$ Autorem pojęcia „sądy synoptyczne” jest Louis G. Mink. Zob. J. Topolski, Jak się pisze i rozumie historię: tajemnice narracji historycznej, Warszawa 1996, s. 82.

${ }^{17}$ E. Babbie, Badania spoteczne w praktyce, Warszawa 2004, s. 141-144; L. Rubisz, Neutralność jako kryterium naukowości politologii, [w:] Podejścia badawcze i metodologie..., s. 177-178.

${ }^{18}$ J. Topolski, op. cit., s. 253. 
istnienie związku między językiem, myślą i formą, co oznacza wyjście w opracowaniach poza opis treści poglądów politycznych w kierunku refleksji o narzędziach uprawiania myśli politycznej oraz formach jej prezentacji przez podmioty. Podmiot polityczny w swoich wypowiedziach nie tylko wyraża treści, ale także eksponuje stosunek do nich, a także sięga po odpowiednie formy, żeby ukryć lub pokazać własne poglądy ${ }^{19}$. Ponadto sytuację w zakresie komunikowania politycznego komplikuje stan opisany przez Andrew Heywooda, według którego pojęcia używane w przekazach przez ich nadawcę są typami idealnymi, projekcjami narzuconymi na rzeczywistość, dlatego też należy je traktować tylko jako „narzędzia umożliwiające rozumienie rzeczy”"20. W naszym przywypadku tymi rzeczami są poglądy polityczne.

Czwartą kotwicą jest niewątpliwie dokonanie standaryzacji badań myśli politycznej. Standaryzacja może przybrać dwie postacie. Pierwszą wskazał Konrad Jajecznik, postulując jej dokonanie na podstawie kryterium ilościowego, czyli opracowanie stosownej skali, wychodząc z założenia, że współczesna nauka i praktyka preferują myślenie $w$ tych kategoriach ${ }^{21}$. Zaczął więc poszukiwać właściwości mierzalnych i stopniowalnych, które pozwoliłyby dokonywać porównań, klasyfikować uczestników stosunków społecznych. W tym celu zaproponował mierzenie występowania wybranych treści, natężenia właściwości oraz siły oddziaływania treści na odbiorców ${ }^{22}$. Chcąc przeprowadzić takie pomiary, należałoby zastosować trzy rodzaje skal: 1) kontinuum stopień natężenia wybranej cechy w postaci wartości $(0,+\infty$, skala porządkowa); 2) spektrum - występowanie przeciwstawnych wartości $(+1,-1$, skala nominalna); 3$)$ diada - badanie hierarchii aksjologicznych oraz dystansu między wartościami niepowiązanymi treściowo i niebędącymi przeciwieństwami (osie dwudzielne, skala interwałowa).

Drugim kierunkiem powinna być standaryzacja wokół zmodernizowanego kwestionariusza poznawczego, czyli o charakterze jakościowym ${ }^{23}$. Konrad Jajecznik zaproponował liczenie ilości użycia w świadectwach myśli politycznej danego jej twórcy i nosiciela wybranego słowa, traktowanego jako kategoria. Wówczas „Częstotliwość stosowania danej kategorii świadczyłaby o jej randze w hierarchii ważności" ${ }^{24}$. Jednak takie podejście metodologiczne ma trzy ważne ograniczenia: 1) liczenie występowania wskaźników jest możliwe tylko w podstawowych świadectwach myśli politycznej; 2) przyjmuje się wielce dyskusyjne założenie, że liczba użycia nazwy danej idei świadczy o jej ważności; 3) nie uwzględnia się stosowania przez twórcę myśli politycznej socjotechniki i propagandy, faktycznie maskujących poglądy polityczne.

\footnotetext{
${ }_{19}$ J. Strzednicki, Logika i jej rola wobec myślenia, [w:] Logiczne podstawy rozumowań, cz. 2, red. L. Kostro, J. Przybyłowski, Gdańsk 1997, s. 21-23.

${ }^{20}$ A. Heywood, Klucz do politologii: Najważniejsze ideologie, systemy, postaci, Warszawa 2008, s. 7.

21 K. Jajecznik, Myśl polityczna - próba standaryzacji badań, „Rocznik Nauk Politycznych” 2006/9, s. 255-256.

22 Ibidem, s. 259.

${ }^{23}$ W. Paruch, Myśl polityczna - refleksje metodologiczne..., s. 31 i n.; idem, Między wyobrażeniami a dziataniami: Wybrane aspekty przedmiotowe badań politologicznych nad myśla polityczna, „Polityka i Społeczeństwo” 2004/1, s. 11-13.

${ }^{24}$ K. Jajecznik, op. cit., s. 257.
} 


\section{KONSEKWENCJA PIERWSZA - POLITYCZNOŚĆ I POLITYKA W MYŚLENIU POLITYCZNYM}

Wielce archaiczne jest redukowanie politologii do badań nad polityką, jak dość powszechnie uważano w Polsce w schyłkowym okresie komunistycznym oraz budowy podstaw państwa demokratycznego. Uznanie, że przedmiotem badań politologicznych jest rzeczywistość polityczna implikuje dwa skutki w odniesieniu do myśli politycznej. Jak już wskazano, należało zmodernizować definicję myśli politycznej oraz jednocześnie rozszerzyć kwestionariusz badań. Błędne były prognozy sprzed 15 lat Ziemowita Jacka Pietrasia o nakładaniu się na siebie dwóch typów zmian zachodzących z jednej strony w rzeczywistości, która ,staje się [...] chaotyczna, turbulentna i trudna do zdefiniowania”, a $\mathrm{z}$ drugiej w myśleniu politycznym zdominowanym przez dekonstrukcję pojęć i struktur ${ }^{25}$. Nie wydaje się, żeby współczesność była bardziej chaotyczna i turbulentna od innych epok historycznych, wystarczy przypomnieć sobie zakres zmian u schyłku starożytności i na początku średniowiecza, na przełomie XVIII i XIX w. oraz w ostatnich dekadach czasów nowożytnych. Istota rzeczywistości politycznej nie uległa zmianom, podobnie jak reguły myślenia politycznego, co nie oznacza, że nie pojawiły się teorie polityczne, których twórcy ogłosili koniec historii, triumf postmodernizmu i dominację konstruktywizmu.

Po pierwsze, polityczność cechuje analizowany przez politologów fragment rzeczywistości społecznej, ale także myśl będącą efektem wysiłku intelektualnego podmiotów jednostkowych i zbiorowych. Autor podziela opinię Ryszarda Skarzyńskiego, że polityczność przedmiotów różnego typu, między innymi wydarzeń, procesów i myśli, jest następstwem uwikłania w konflikt - albo są następstwem konfliktu, albo go wywołują; ich skutkiem jest zaś polaryzacja i konsolidacja w stosunkach społecznych ${ }^{26}$. W odniesieniu do konfliktu, każdy podmiot polityczny z powodów egzystencjalnych jest zainteresowany $\mathrm{w}$ odniesieniu zwycięstwa, co oznacza pokonanie antagonistów lub zniesienie sytuacji zagrożenia. Chcąc osiągnąć sukces, podmiot polityczny w sposób nieskrępowany stara się sięgać po środki polityczne, którymi także mogą stać się uprzedmiotowione inne byty. Kompromis osiągany w wyniku negocjacji oraz towarzysząca mu równowaga są stanem jedynie tymczasowym w oczekiwaniu na decydujące starcie, na danym terytorium bowiem nie mogą wspólistnieć dwa alternatywne i konkurencyjne wobec siebie wizje ładu społecznego. Wszelkie techniki negocjacyjne i gry polityczne służą przygotowaniu jak najlepszych warunków, aby odnieść zwycięstwo.

Biorąc pod uwagę polityczność jako cechę rzeczywistości społecznej, należy zauważyć dwie podstawowe funkcje myśli politycznej. Primo, to właśnie ona konstytuuje podmiot polityczny, nadając mu tożsamość, niezbędną dla jego egzystencji i rywalizacji z wrogami. Głównym składnikiem tożsamości podmiotu politycznego jest własna wizja pożądanego ładu społecznego, który zamierza zaprowadzić na opanowanej przez siebie przestrzeni w wyniku przejęcia władzy. Wokół tej wizji powstają z jednej strony przeżycia zbiorowe, a z drugiej kultura symboliczna zawarta między innymi w zabytkach i mitach. Secundo, myśl polityczna zawiera sposób postrzegania stosunków społecznych,

${ }^{25}$ Z.J. Pietraś, Politologia ideologiczna, behawioralna..., s. 40.

${ }^{26}$ R. Skarzyński, Intelektualiści a ideologia: myśl polityczna jako przedmiot badań politologa, „Studia Nauk Politycznych” 1990/4-5, s. 10; szerzej zob. idem, Wróg i sojusznik: studium struktury myśli politycznej, „Studia Nauk Politycznych” 1990/1-3, s. 59-88. 
przede wszystkim ich ocenę, strukturalizację areny rywalizacyjnej za pomocą kategorii wróg i sojusznik, strategię i taktykę postrzeganą jako warunek odniesienia zwycięstwa. Każdy twórca myśli politycznej, chcąc zachować swoje istnienie jako podmiot niespenetrowany w stosunkach społecznych, określa wrogów zarówno w ujęciu podmiotowym, jak i w sensie rzeczowym, czyli momenty i procesy polityczne prowadzące do utraty racji funkcjonowania w przestrzeni publicznej. W tych problemach zawierają się zadania poznawcze współczesnych politologów w odniesieniu do badania myśli politycznej.

Po drugie, pole badań politologicznych przyjmuje postać trójkąta. Na każdym z trzech wierzchołków tak określonego pola badań myśl polityczna spełnia inną funkcję. Efektem działań politycznych są decyzje podejmowane lub niepodejmowane przez podmioty polityczne - zarówno sprawujące rządy, jak również będące w opozycji. Jedynie w pierwszym wypadku decyzje polityczne przekształcają się w przepisy prawne, na których straży stoją organy państwa.

Rys. 1. Pole badań politologicznych

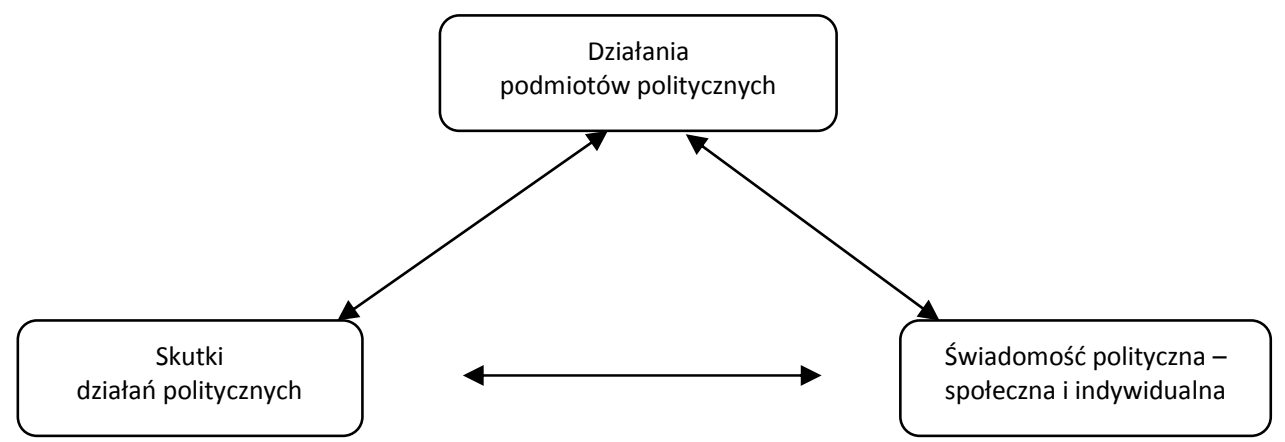

Źródło: opracowanie własne.

„Teoria jest ważna dla polityki” - ta prosta konstatacja Janusza Goćkowskiego wskazała na konieczność skierowania badań myśli politycznej na nowe tory w postaci analizy wykorzystywania przez podmioty polityczne (polityków, ugrupowania polityczne) teorii uznawanych za naukowe w danym czasie historycznym, należy pamiętać, że wzorce naukowości ulegają zmianom ${ }^{27}$. W działalności ideotwórczej poznanie naukowe jest wykorzystywane instrumentalnie w następujących celach: 1) opisuje i objaśnia rzeczywistość polityczną; 2) pozwala tworzyć stereotyp zrozumienia prawdy o ogólnej naturze rzeczywistości oraz o szczegółowych wydarzeniach i procesach; 3) umożliwia projektowanie pożądanego stanu rzeczywistości oraz prognozowanie następnych stadiów procesów politycznych; 4) dostarcza wiedzy o możliwości zrealizowania własnych idei;

27 J. Goćkowski, Uczony i polityk: zbieżność i rozbieżność interesów oraz aspiracji, „Nauka” $2006 / 4$,

R. Skarzyński, Historia myśli politycznej w ujęciu politologicznym: zarys koncepcji, „Studia Polityczne" 1992/1, s. 107-119; T. Uliński, Opis i wyjaśnianie: zarys problematyki, [w:] Elementy teorii polityki, red. K. Opałek, Warszawa 1989, s. 49-52; R. Dunbar, Kłopoty z nauka, GdańskWarszawa 1996, s. 23 i n. 
5) wyposaża polityków w terminy teoretyczne niezbędne do sformułowania warstwy ideologicznej myśli politycznej; 6) nadaje politykom kompetencje epistemiczne, wykorzystywane w legitymizacji ich roszczeń władczych ${ }^{28}$.

Każdy podmiot polityczny w działalności ideotwórczej dokonuje rozstrzygnięć o polityce w sensie ogólnym i szczegółowym. W pierwszym kontekście odpowiada na pytanie o metody i środki preferowane w procesie zdobywania władzy. Bynajmniej nie chodzi tylko o rozstrzygnięcia systemowe - o akceptację dla wyborów demokratycznych, autorytarnego zamachu stanu, czy też totalitarnej rewolucji lub przebudowy międzysystemowej, ale o przemyślenia na temat technik socjotechnicznych i propagandowych. Na etapie bycia w opozycji, sięgania po władzę lub co najmniej po jej osiągnięciu podmioty polityczne formułują koncepcje i programy polityczne w zakresie wybranej polityki szczegółowej, w rzeczywistości bowiem tylko w ten sposób można z jednej strony zaspokoić własne interesy polityczne, a z drugiej osiągnąć pożądane skutki społeczne korzystne dla egzystencji danego podmiotu politycznego. Zdobycie władzy w państwie jest konieczne, gdyż pozwala dość efektywnie dokonywać polityzacji wybranych zjawisk społecznych, ale nie stwarza żadnych gwarancji, że deklarowane cele zostaną zrealizowane. Jest potrzebna koncepcja chociażby polityki gospodarczej, społecznej, zagranicznej, wojskowej, oświatowej, z której będą wynikały konkretne programy przybierające postać przepisów prawnych i wykonanych decyzji politycznych. Rys. 2. Pole politologicznych badań myśli politycznej

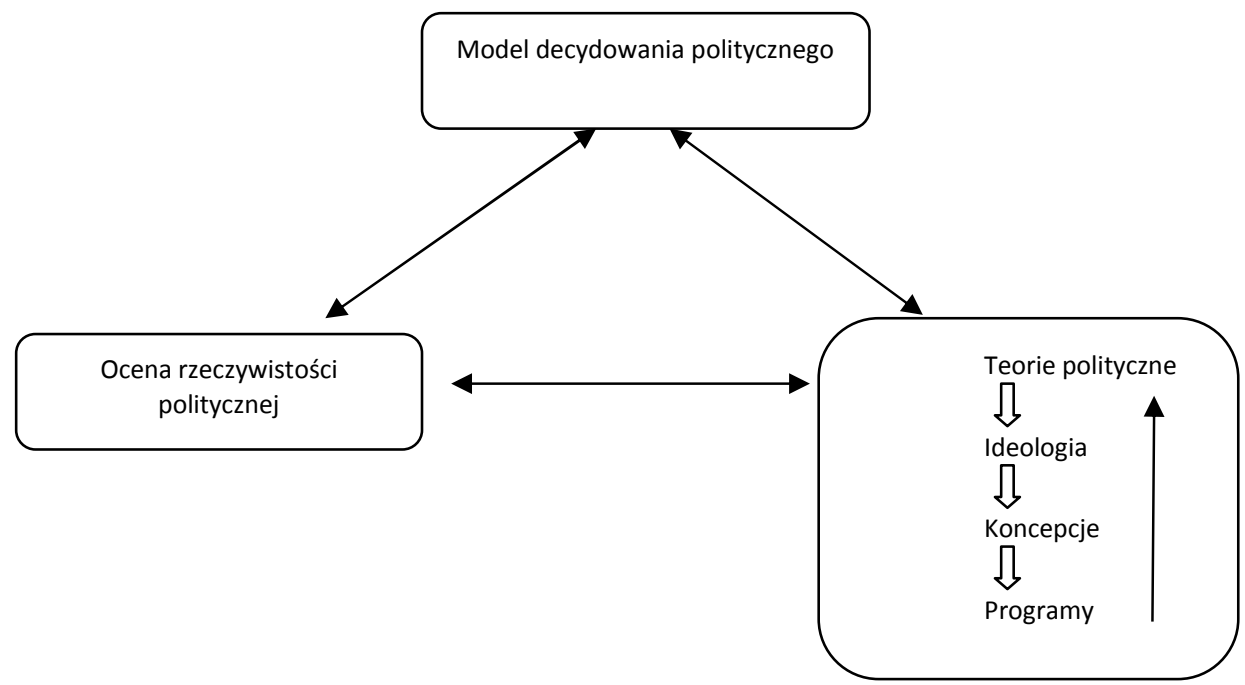

Źródło: opracowanie własne.

Twórcy myśli politycznej formułują własny model decydowania politycznego lub adaptują zapożyczony, kierując się kryteriami zdroworozsądkowymi bądź korzystając z doradztwa specjalistycznego. W sensie organizacyjnym polityka rzeczywiście polega na sposobie podejmowania decyzji politycznych, ale „dzieje się” na trzech poziomach:

${ }^{28}$ J. Goćkowski, op. cit., s. 74. 
refleksyjnym, ogólnym i szczegółowym. Ten stan w generalnym uproszczeniu polega na formułowaniu przez podmiot polityczny projektów działań podejmowanych co do: określenia zakresu, zasięgu oraz rozgraniczenia przestrzeni publicznej i sfery prywatnej, rywalizacji o przejęcie władzy w państwie, rozwiązywania konfliktowych kwestii w różnych dziedzinach stosunków społecznych. Szczególnym przedmiotem zainteresowania politologów powinno być wykorzystywanie w działalności ideotwórczej teorii naukowych, które w ten sposób nie tylko uzyskują kontekst polityczny, ale również są wykorzystywane $\mathrm{w}$ diagnozowaniu rzeczywistości oraz projektowaniu polityki. Specyficzną rolę podmiot polityczny przypisuje teoriom społecznym. Czerpiąc z ich dość szerokiego wachlarza, formułuje własny sposób strukturalizacji stosunków społecznych oraz wyjaśniania ich konfliktowości. Jeśli uznać podział na wrogów i sojuszników za jeden $\mathrm{z}$ dwóch ostatecznych podziałów politycznych - oprócz podziału na podmioty i środki polityczne - to poszczególni twórcy myśli politycznej mogą opisywać zarówno wroga, jak i sojusznika za pomocą różnych słów. Najważniejsza jest kwestia rygoryzmu w odniesieniu do wroga, czyli odpowiedź na pytanie - czy przewiduje się z wrogiem politycznym utrzymywanie podmiotowych relacji pozapolitycznych ${ }^{29}$.

W rys. 2 zaprezentowano proces weryfikacji zachodzący między warstwami myśli politycznej. Kierując się teoriami politycznymi, niekiedy wybieranymi w sposób eklektyczny, podmiot polityczny tworzy własną ideologię, która stanowi system wartości. Są nimi zarówno sądy przypisujące przedmiotom, własnościom, stanom rzeczy lub procesom cechy pożądane, uznane za właściwe i słuszne moralnie, jak również obiekty angażujące wolę ich posiadania. Oba typy wartości ulegają dość łatwo polityzacji, podmiot polityczny będący twórcą myśli politycznej i ośrodkiem decyzyjnym narzuca bowiem ich powszechną akceptację jako cel aktywności społecznej, czyni z nich środek w dokonywaniu konsolidacji politycznej, wymusza powszechny szacunek, stosuje je także do oceny innych uczestników stosunków społecznych ${ }^{30}$. Jak zauważył Jacek H. Kołodziej: „Publiczne deklarowanie «kierowania się wartościami» stało się niemal obligatoryjnym składnikiem manifestowania politycznej tożsamości" 31 .

Ideologia staje się podstawą aksjologiczną dla koncepcji politycznych, które są wykonywane w postaci programów, formułowanych zarówno w okresie bycia w opozycji, jak i w czasie sprawowania władzy w państwie. Jednak brak spodziewanych efektów oraz generalne zagrożenie dla egzystencji podmiotu politycznego mogą spowodować dekompozycję ideową w postaci zmian aksjologicznych i teoretycznych.

\footnotetext{
29 Zob. D. Drałus, Esencjalizm w koncepcji polityczności Carla Schmitta, [w:] Polityka $i$ polityczność..., s. 158.

${ }^{30}$ Z. Najder, Wartości i oceny, Warszawa 1971, s. 64; S. Nowak, Postawy, wartości i aspiracje społeczeństwa polskiego: przestanki do prognozy na tle przemian dotychczasowych, [w:] Spoteczeństwo polskie czasu kryzysu, red. S. Nowak, Warszawa 1984, passim; J. Szczepański, Elementarne pojęcie socjologii, Warszawa 1970, s. 97-98; S. Jałowiecki, Struktura systemu wartości: studium zróżnicowań międzygeneracyjnych, Warszawa-Wrocław 1978, s. 13-18.

${ }^{31}$ J.H. Kołodziej, op. cit., s. 187.
} 


\section{KONSEKWENCJA DRUGA - ŚLADY I ŚWIADECTWA MYSLI POLITYCZNEJ}

W odniesieniu do badań myśli politycznej zarysował się formalny problem, który wyniknął z istnienia dwóch subdyscyplin - historii myśli politycznej i myśli politycznej. $\mathrm{O}$ ile pierwsza jest dziedziną historii, o tyle druga jest zaliczana do politologii. Natomiast obie dyscypliny zostały rozdzielone w wyniku zaklasyfikowania historii do nauk humanistycznych, a nauki o polityce do nauk społecznych. To przedsięwzięcie jest całkowicie bezzasadne od strony poznawczej, zważywszy, że przedmiotem refleksji naukowej w obu grupach nauk jest albo przeszłość, albo przyszłość, podczas gdy teraźniejszość z racji swojej nieuchwytnej natury nie może być analizowana.

Podmioty polityczne są ośrodkami, w których zachodzą dwa procesy: myślenie polityczne oraz decydowanie polityczne. Obowiązkiem badaczy myśli politycznej jest analizowanie tych dwóch zjawisk, które stały się najważniejszymi kategoriami nowoczesnego kwestionariusza badawczego. Wymienione procesy przenikają się na dwóch płaszczyznach: aksjologiczno-strategicznej i techniczno-pragmatycznej. Każde myślenie polityczne jest oparte na wartościach, które stanowią kategorie konstytutywne i zarazem porządkujące, na przykład państwo, wspólnota polityczna, wspólnota etniczna, człowiek, wybrana grupa społeczna. Każdy podmiot polityczny formułuje strategię polityczną, która ma zapewnić osiągnięcie deklarowanych lub ukrywanych celów. To właśnie wartości prymarne przesądzają też o: 1) decydowaniu politycznym, a przede wszystkim o decyzjach strategicznych; 2) polityce w ujęciu refleksyjnym, czyli o granicy między przestrzenią publiczną a sferą prywatną oraz instytucjach monitorujących to rozgraniczenie.

Jednak można zauważyć rozbieżności między ideami będącymi efektem myślenia politycznego a wykonywanymi decyzjami politycznymi w odniesieniu do podmiotów politycznych zarówno rządzących, jak i opozycyjnych. Każdy uczestnik rywalizacji politycznej o władzę zderza się z cechami rzeczywistości politycznej oraz podlega regułom socjotechniki i propagandy. Józef Lewandowski podkreślił odmienność kształtowania się myśli politycznej ugrupowań opozycyjnych i rządzących; w tej kwestii działają kryterium odpowiedzialności za państwo oraz możliwość dostępu do rzetelnych informacji ${ }^{32}$. Jest to druga płaszczyzna - techniczno-pragmatyczna - przenikania się myślenia politycznego i decydowania politycznego. Decydenci, a zarazem twórcy myśli politycznej, konfrontują własne idee z możliwościami ich realizacji. Analiza może prowadzić do dwóch różnych wniosków: pierwszy - implementacja idei jest niewykonalna z różnych powodów lub nieefektywna politycznie; drugi - własne idee nie uzyskałyby aprobaty społecznej lub mogłyby zagrażać utratą władzy bądź uniemożliwiałyby przejęcie rządów w państwie. $Z$ tych powodów nie wszystkie decyzje mogą służyć realizacji własnej myśli politycznej, lecz wynikają z oceny rzeczywistości, połączonej z przekonaniem, że $\mathrm{w}$ danej sytuacji nie jest możliwe urzeczywistnianie autorskich projektów politycznych. W tych warunkach reguły socjotechniki i propagandy mają pierwszeństwo przed działalnością ideotwórczą, dlatego też ustalanie myśli politycznej danego twórcy jest bardziej wiarygodne na podstawie analizy podejmowanych decyzji niż deklarowanych koncepcji i programów. Rzeczywistość polityczna jest w

32 J. Lewandowski, Imperializm stabości: Kształtowanie się koncepcji polityki wschodniej pitsudczyków 1921-1926, Warszawa 1967, s. 7. 
rzeczywistości zbiorem powiązanych ze sobą sytuacji, które „zawierają problemy do rozwiązania, a to wymaga od polityka wyobraźni, pomysłowości, twórczości [...]"33.

Opisane zależności wymuszają wykorzystywanie w badaniach politologicznych śladów i świadectw myśli politycznych. Pierwszy typ źródeł jest zapisem podjętych decyzji politycznych, przy całej złożoności tej kategorii politologicznej. Przedmiotowe podejście z jednej strony otworzyło możliwość wykorzystywania w politologicznych badaniach myśli politycznej analizy decyzyjnej, a z drugiej strony znacznie rozszerzyło podstawę źródłową dociekań naukowych o bardzo liczne ślady po podjętych decyzjach. Wyjątkowo ważna jest refleksja nad tą fazą decydowania politycznego, kiedy ośrodek decyzyjny rozważa różne alternatywne warianty, przypisuje im cechy rozwiązań maksymalistycznych, minimalistycznych, optymalnych -wybiera jeden z nich, odrzucając pozostałe. Wtedy w śladach myśli politycznej badacz odnajdzie ocenę sytuacji decyzyjnej w ujęciu informacyjnym i bodźcowym, dane na temat decydenta (charakter, osobowość, racjonalność, wiedza), uzasadnienie podjętej decyzji oraz powody odrzucenia dostrzeganych konkurencyjnych rozwiązań, katalog pożądanych skutków, motywacje sterujące zachowaniami twórcy myśli politycznej.

Natomiast świadectwa myśli politycznej są źródłami klasycznymi dla badaczy myśli politycznej. Zalicza się do nich różnego rodzaju wystąpienia publiczne, dokumenty opublikowane, zapisy dyskusji ideologiczno-programowych, wytwory prasowe, utwory pamiętnikarskie oraz wszelkie inne nowoczesne formy przekazu typu audiowizualnego z wykorzystaniem telewizji, radia i internetu. Świadectwa myśli politycznej pozwalają ustalić dwie kategorie myśli politycznej: 1) typy czyste zbudowane wokół rdzenia ideologii; 2) hybrydy ideowe.

Zarówno ślady, jak i świadectwa myśli politycznej dostarczają politologom wskaźników myśli politycznej, dostępnych w sposób empiryczny lub hermeneutyczny. To właśnie wskaźniki pozwalają z jednej strony poznać twórcę idei, dostarczając danych na jego temat, $\mathrm{z}$ drugiej zaś przekazać informacje o decyzjach, które podmiot polityczny zamierza podjąć po przejęciu władzy w państwie. Dla badań myśli politycznej wyjątkowo ważny jest imperatyw poznawczy, który przede wszystkim odnosi się do warstwy programowej myśli politycznej. Tę prawidłowość opisał Wojciech Sokół na przykładzie partii politycznych, wskazując, że programy nie są konceptem działań politycznych, lecz wyrazem propagandy stosowanej w celu maksymalizacji doraźnych korzyści (w tym wypadku autorowi chodziło o rozszerzenie bazy wyborczej oraz odróżnienie się od konkurentów na arenie politycznej) ${ }^{34}$. Najczęściej są wykorzystywane dwa środki semantyczne: 1) upublicznianie ocen rzeczywistości nieadekwatnych do opinii prezentowanych we własnym środowisku (opozycja wieszczy katastrofę, a rządzący głoszą historyczne sukcesy); 2) składanie obietnic niemożliwych do wykonania w zastanych warunkach. Jeśli w odniesieniu do danego podmiotu politycznego występują zasadnicze sprzeczności między śladami a świadectwami, to wówczas uznaje się za wiarygodne ślady, czyli zapisy o decydowaniu politycznym. To one przesądzają o charakterze myśli politycznej, a świadectwa są skażone socjotechniką i propagandą.

\footnotetext{
${ }^{33}$ J. Goćkowski, op. cit., s. 77.

${ }^{34}$ W. Sokół, Funkcje partii politycznych, [w:] Wspótczesne partie i systemy partyjne: Zagadnienia teorii i praktyki politycznej, red. W. Sokół, M. Żmigrodzki, Lublin 2003, s. 72-77.
} 


\section{KONSEKWNECJA TRZECIA - TYPY I ZAKRES KWESTIONARIUSZY BADAWCZYCH}

Badanie myśli politycznej należy oprzeć na trzech kwestionariuszach, które są narzędziami badawczymi $\mathrm{w}$ odniesieniu do myśli politycznej: uniwersalnym, historycznym i specyficznym (rys. 3).

Pierwsze narzędzie ma charakter uniwersalny i obejmuje katalog pytań badawczych, które należy stawiać wobec wszystkich twórców myśli politycznej niezależnie od epoki historycznej. Pyta się o poglądy polityczne na najważniejsze kwestie życia społecznego, a przede wszystkim o kryterium polaryzacji politycznej, sposób konsolidacji politycznej, model polityki, decydowanie polityczne. Te problemy są ze swej istoty polityczne ,poza czasem i przestrzenią". Drugi kwestionariusz powinien być dostosowany do okresu historycznego oraz właściwych mu systemów politycznych. W każdej epoce występują wiodące kwestie polityczne, które strukturalizują arenę polityczną. Trzeci kwestionariusz należałoby określić jako specyficzny, czyli odnoszący się albo do zbioru podmiotów politycznych (np. rodzina demokratycznych partii politycznych, obozy autorytarne, monopartie totalitarne), albo do jednego konkretnego obiektu analizy. Pochodzenie kwestionariusza specyficznego klarownie wyjaśnił Konrad Jajecznik, przywołując indywidualne właściwości przedmiotu poznania oraz potrzeb badacza zdeterminowanych przez wyznaczone zadania analityczne ${ }^{35}$.

Rys. 3. Kwestionariusze badawcze myśli politycznej

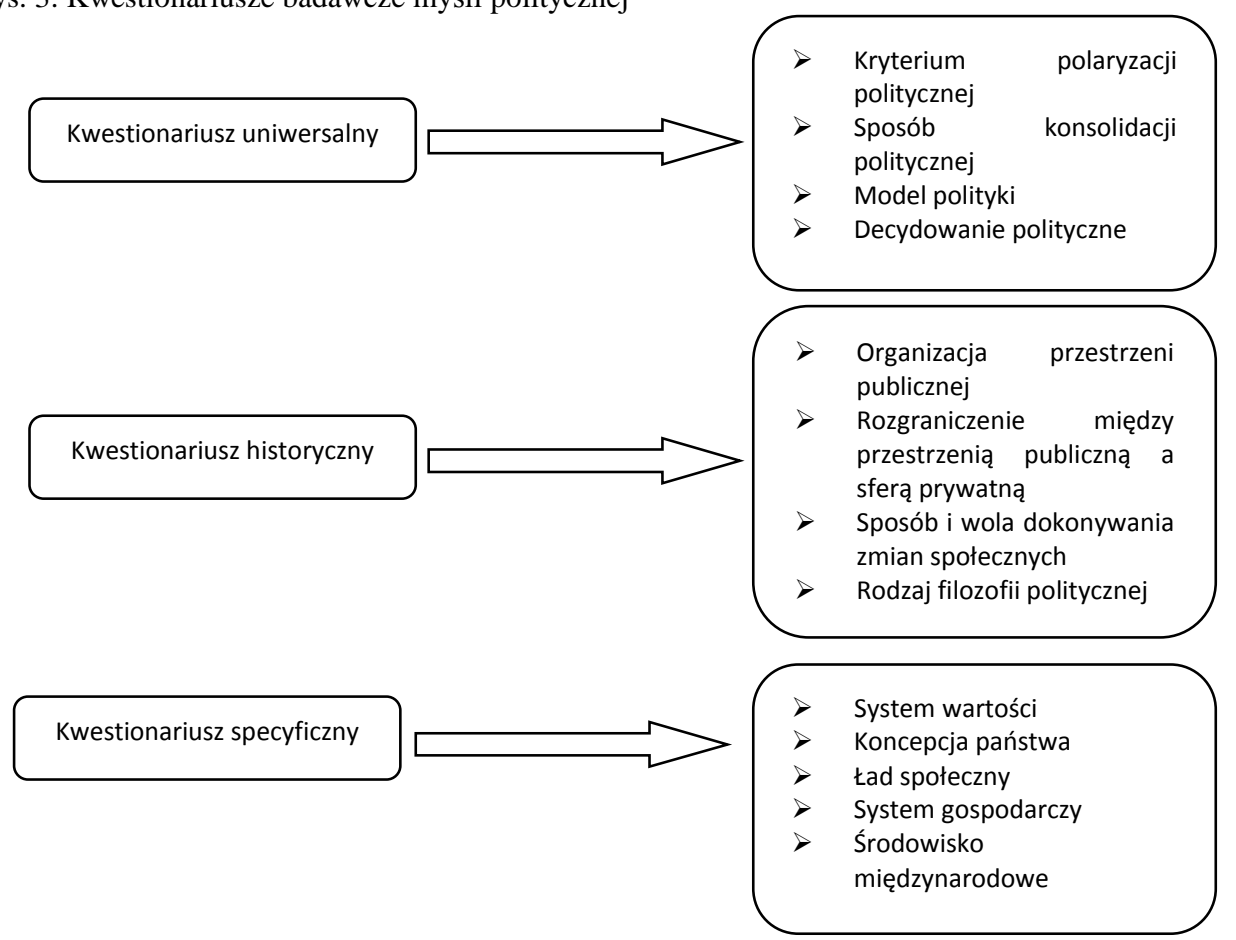

Źródło: opracowanie własne.

\footnotetext{
${ }^{35}$ K. Jajecznik, op. cit., s. 268.
} 
W dwóch pierwszych kwestionariuszach - uniwersalnym i historycznym - wyjątkowo ważną funkcję spełniają refleksje na płaszczyznach: systemowej i epistemicznej. Na pierwszej płaszczyźnie podmiot polityczny dokonuje rozstrzygnięć w zakresie organizacji przestrzeni publicznej oraz rozgraniczenia między przestrzenią publiczną a sferą prywatną. Natomiast w odniesieniu do epistemologii wyjątkowo ważne są przemyślenia w odniesieniu do: roli w poznaniu i decydowaniu rozumu, emocji i afektów; racjonalności, czyli rozstrzygnięcia przedmiotu wyboru - cele czy środki - oraz źródeł pochodzenia wartości politycznych; działalności politycznej - zapewnienie egzystencji czy zaspokajanie potrzeb; oceny możliwości, szans i woli dokonywania zmian społecznych. W kwestionariuszu specyficznym, wiodącą rolę odgrywa analiza poglądów politycznych w czterech grupach zagadnień: 1) system wartości; 2) koncepcja państwa; 3) ład społeczny w ujęciu społeczno-ekonomicznym, narodowo-etnicznym i religijnowyznaniowym; 4) system gospodarczy w odniesieniu do podstaw gospodarki, mechanizmu wzrostu oraz regulacji w gospodarce; 5) środowisko międzynarodowe w rozumieniu globalnym, kontynentalnym i regionalnym.

Celem kwestionariusza specyficznego jest ustalenie struktury ideowo-programowej badanej myśli politycznej, czyli stylu myślenia. Na styl myślenia składają się dwie grupy wartości: dominanty - stabilne, bezwarunkowe i niezmienne w wymiarze co najmniej jednego pokolenia; zależne - podporządkowane, interpretowane i postrzegane w kontekście sytuacyjnym oraz czasowym ${ }^{36}$. Ponadto podmioty polityczne będą się różniły między sobą poziomem dogmatyzmu lub instrumentalizowania wartości ${ }^{37}$. Jednoczesne wykorzystanie kwestionariuszy historycznego i specyficznego pozwala wyłączyć z myśli politycznej wybranego podmiotu $\mathrm{w}$ danym czasie i konkretnej przestrzeni dwie grupy poglądów: pierwszą stanowią rozważania teoretyczne, filozoficzne i moralne, a do drugiej zalicza się poglądy specjalistyczne $\mathrm{z}$ zakresu kwestii społecznych, prawnych, kulturalnych, medycznych, historycznych, gospodarczych i wojskowych. W obu wypadkach nie mają charakteru politycznego, a więc nie zawierają się w polu zainteresowań politologów, lecz innych dyscyplin naukowych, takich jak filozofia, etyka, naukoznawstwo, ekonomia, socjologia, historia, prawoznawstwo, kulturoznawstwo, medycyna $^{38}$.

Idee (projekty, programy) stają się polityczne w określonych sześciu przypadkach konkretno-historycznych (rys. 4), które zostały wydzielone w oderwaniu od instytucji władczych, organów państwowych i interesów politycznych, lecz w ujęciu procesualnym i funkcjonalnym, polityzacja bowiem jest procesem oraz, zachodząc, powoduje, że idea $\mathrm{w}$ pierwotnym sensie zmienia swoją rolę społeczną - jest wykorzystywana do polaryzacji, konsolidacji i rywalizacji zachodzących w społeczeństwie. Natomiast trzy kwestionariusze, traktowane łącznie, powinny posłużyć do skonstruowania mapy myśli

\footnotetext{
${ }^{36}$ S. Jałowiecki, op. cit., s. 21; A. Czarnota, op. cit., s. 278-279.

${ }^{37} \mathrm{O}$ poznawalności wartości oraz ograniczeniach w tej materii pisał Roman Ingarden. Zob. R. Ingarden, Czego nie wiemy o wartościach, [w:] idem, Studia z estetyki, t. 3, Warszawa 1970, s. 220 243.

${ }^{38}$ Analiza problemu relacji między politycznością a kwestiami ekonomicznym - zob. W. Paruch, Kategorie ekonomiczne a zakres pojęcia „myśl polityczna” - refleksje metodologiczne, [w:] Idee Państwo - Ludowcy: Księga jubileuszowa z okazji 70. rocznicy urodzin Profesora Jana Jachymka, red. E. Maj, S. Michałowski, A. Wójcik, Lublin 2009, s. 37-46.
} 
politycznej, która byłaby narzędziem służącym do poszukiwania powiązań między ideami, ułatwiającym analizowanie wybranego twórcy myśli politycznej oraz prowadzonej przez niego działalności ideotwórczej ${ }^{39}$. W odniesieniu do współczesności klasyfikowanie oznacza pozycjonowanie podmiotu politycznego na osi prawica-centrumlewica.

Rys. 4. Polityzacja idei

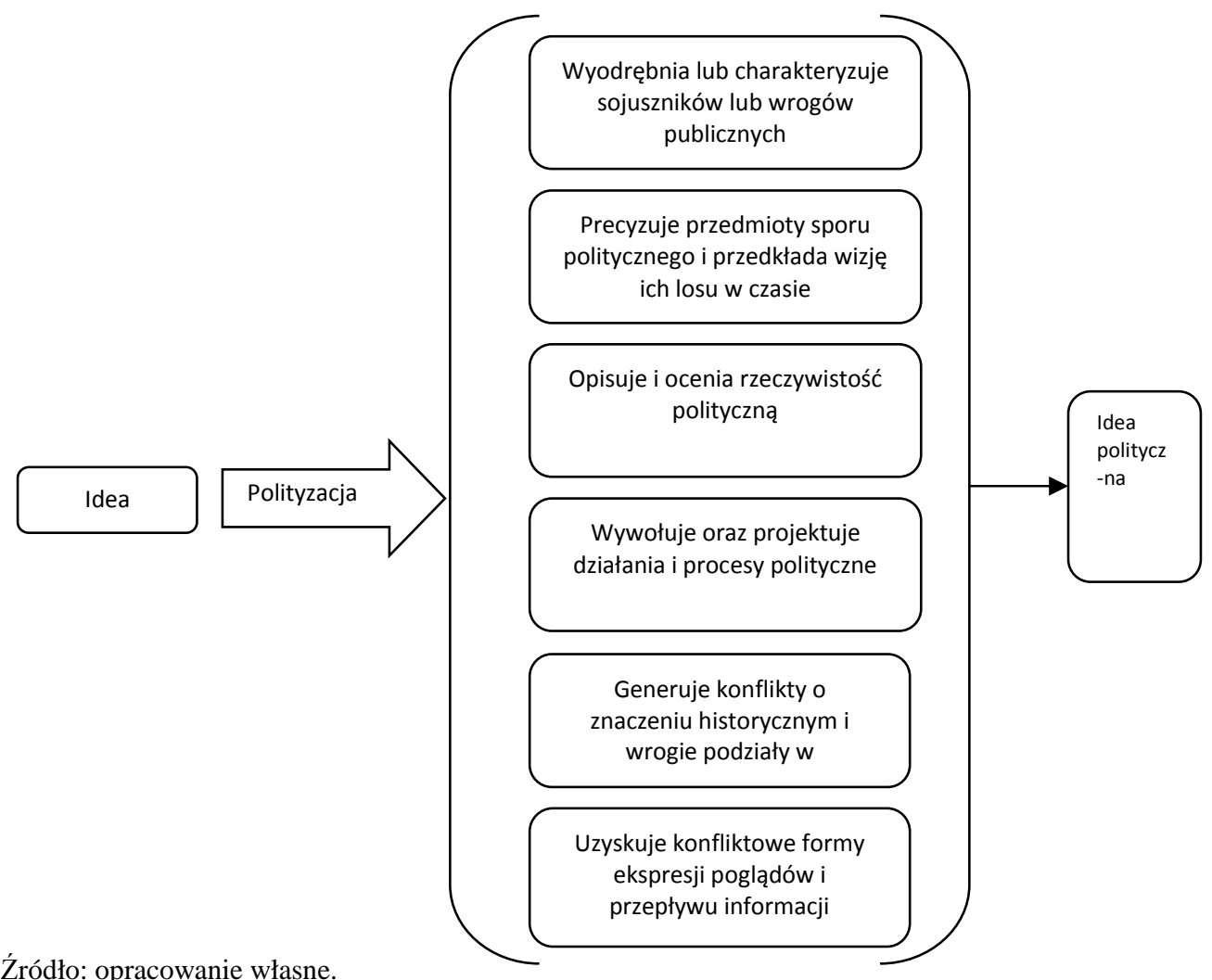

Z dokonanej analizy wynika, że zasadnicze zmiany w definiowaniu myśli politycznej, jakie dokonały się w pierwszej dekadzie XXI w., generują potrzebę wyznaczania nowych zadań badawczych. Nowe wyzwania (powinności) pojawiły się dla politologów w związku z trzema potrzebami poznawczymi; są to: 1) badanie poglądów podmiotów politycznych pod względem polityczności i polityki; 2) rozszerzenie bazy źródłowej o ślady myśli politycznej; 3) dokonanie standaryzacji badań politologicznych realizowanych w tej subdyscyplinie.

\footnotetext{
${ }^{39}$ K. Jajecznik, op. cit., s. 265.
} 


\section{LITERATURA}

[1] Babbie E., Badania spoteczne w praktyce, Warszawa 2004.

[2] Czajowski A., Polityczność dziatań spotecznych, [w:] Polityka $i$ polityczność: Problemy teoretyczne i metodologiczne, red. A. Czajowski, L. Sobkowiak, Wrocław 2012.

[3] Czarnota A., Problemy syntezy polskiej myśli politycznej - rozważania wstępne, [w:] Polska myśl polityczna XIX i XX wieku, t. 7: Państwo w polskiej myśli politycznej, red. W. Wrzesiński, Wrocław-Warszawa-Kraków-GdańskŁódź 1988.

[4] Drałus D., Esencjalizm w koncepcji polityczności Carla Schmitta, [w:] Polityka $i$ polityczność: Problemy teoretyczne $i$ metodologiczne, red. A. Czajowski, L. Sobkowiak, Wrocław 2012.

[5] Dunbar R., Ktopoty z nauka, Gdańsk-Warszawa 1996.

[6] Goćkowski J., Uczony i polityk: zbieżność i rozbieżność interesów oraz aspiracji, ,Nauka” 2006/4.

[7] Heywood A., Klucz do politologii: Najważniejsze ideologie, systemy, postaci, Warszawa 2008.

[8] Ingarden R., Czego nie wiemy o wartościach, [w:] idem, Studia z estetyki, t. 3, Warszawa 1970.

[9] Jachymek J., Paruch W., Wstęp, [w:] Więcej niż niepodległość: Polska myśl polityczna 1918-1939, red. J. Jachymek, W. Paruch, Lublin 2001.

[10] Jajecznik K., Myśl polityczna - próba standaryzacji badań, „Rocznik Nauk Politycznych" 2006/9.

[11] Jałowiecki S., Struktura systemu wartości: studium zróżnicowań międzygeneracyjnych, Warszawa-Wrocław 1978.

[12] Jaskólski M., Szkice o historii doktryn politycznych i prawnych, Warszawa-Kraków 1985.

[13] Klementewicz T., Politologia tradycyjna a politologia teoretyczna $w$ poszukiwaniu modelu metodologicznego nauki o polityce, „Studia Polityczne” 1992/1.

[14] Klementewicz T., Spór o model metodologiczny nauki o polityce, Warszawa 1991.

[15] Kołodziej J.H., Wartości polityczne - problem badawczy dla politologa, [w:] Podejścia badawcze i metodologiczne w nauce o polityce, red. B. KrauzMozer, P. Ścigaj, Kraków 2013.

[16] Krauz-Mozer B., Szostak W., Teoria polityki: podstawy metodologiczne politologii empirycznej, Kraków 1993.

[17] Krauz-Mozer B., Ścigaj P., Sklep z podróbkami? Podejścia badawcze i metodologie w nauce o polityce, [w:] Podejścia badawcze i metodologiczne w nauce o polityce, red. B. Krauz-Mozer, P. Ścigaj, Kraków 2013.

[18] Lewandowski J., Imperializm słabości: Ksztattowanie się koncepcji polityki wschodniej pitsudczyków 1921-1926, Warszawa 1967.

[19] Łuczak A., Społeczeństwo i państwo $w$ myśli politycznej ruchu ludowego, Warszawa 1982.

[20] Najder Z., Wartości i oceny, Warszawa 1971. 
[21] Nowak S., Postawy, wartości i aspiracje spoteczeństwa polskiego: przestanki do prognozy na tle przemian dotychczasowych, [w:] Społeczeństwo polskie czasu kryzysu, red. S. Nowak, Warszawa 1984.

[22] Nowakowski Z., Bezpieczeństwo państwa w koncepcjach programowych partii parlamentarnych w Polsce po 1989 roku, Warszawa 2009.

[23] Paruch W., Kategorie ekonomiczne a zakres pojęcia „myśl polityczna” refleksje metodologiczne, [w:] Idee - Państwo - Ludowcy: Księga jubileuszowa z okazji 70. rocznicy urodzin Profesora Jana Jachymka, red. E. Maj, S. Michałowski, A. Wójcik, Lublin 2009.

[24] Paruch W., Między wyobrażeniami a dziataniami: Wybrane aspekty przedmiotowe badań politologicznych nad myśla polityczna, „Polityka i Społeczeństwo" 2004/1.

[25] Paruch W., Myśl polityczna - refleksje metodologiczne o pojęciu, „Annales Universitatis Mariae Curie-Skłodowska, Sectio K: Politologia” 1999/6.

[26] Paruch W., Myśl polityczna obozu pitsudczykowskiego 1916-1939, Lublin 2005.

[27] Paruch W., Myśl polityczna we wspótczesnej polskiej politologii: modernizacja przedmiotu, strategii i metody badań, [w:] Politologia w Polsce: Stan i perspektywy, red. M. Cichosz, K. Zamorska, Wrocław 2006.

[28] Pietraś Z.J., Politologia ideologiczna, behawioralna czy postmodernistyczna, [w:] Politologia $w$ szkolnictwie wyższym w Polsce, red. E. Olszewski, Lublin 1997.

[29] Pietraś Z.J., Teoria decyzji politycznych, Lublin 1990.

[30] Rittel S., Zjawiska polityczne w ujęciu systemowym, „Zeszyty Naukowe Politechniki Krakowskiej. Nauki Ekonomiczne" 1989/2.

[31] Rubisz L., Neutralność jako kryterium naukowości politologii, [w:] Podejścia badawcze i metodologiczne $w$ nauce o polityce, red. B. Krauz-Mozer, P. Ścigaj, Kraków 2013.

[32] Ryszka F., [rec. Polska myśl polityczna XIX i XX wieku, t. 1: Polska i jej sąsiedzi, red. H. Zieliński, Wrocław-Warszawa-Kraków-Gdańsk 1975], „Odra” 1976/5.

[33] Skarzyński R., Historia myśli politycznej w ujęciu politologicznym: zarys koncepcji, „Studia Polityczne” 1992/1.

[34] Skarzyński R., Intelektualiści a ideologia: myśl polityczna jako przedmiot badań politologa, ,Studia Nauk Politycznych” 1990/4-5.

[35] Skarzyński R., Monizm i pluralizm $w$ rozwoju dyscypliny nauki: politologia i pseudopolitologia, [w:] Przedmiot poznania politologii: Podstawy dyscypliny nauki, red. R. Skarzyński, Białystok 2014.

[36] Skarzyński R., Podstawowy dylemat politologii I (2010), [w:] Przedmiot poznania politologii: Podstawy dyscypliny nauki, red. R. Skarzyński, Białystok 2014.

[37] Skarzyński R., Podstawowy dylemat politologii: Dyscyplina nauki czy potoczna wiedza o spoteczeństwie? O tradycji uniwersytetu i demarkacji wiedzy, Białystok 2012.

[38] Skarzyński R., Przedmiot poznania politologii, [w:] Przedmiot poznania politologii: Podstawy dyscypliny nauki, red. R. Skarzyński, Białystok 2014. 
[39] Skarzyński R., Wróg i sojusznik: studium struktury myśli politycznej, „Studia Nauk Politycznych” 1990/1-3.

[40] Sobolewski M., Niektóre problemy teorii i metodologii historii doktryn politycznych, „Historyka” 1976/6.

[41] Sokół W., Funkcje partii politycznych, [w:] Wspótczesne partie i systemy partyjne: Zagadnienia teorii i praktyki politycznej, red. W. Sokół, M. Żmigrodzki, Lublin 2003.

[42] Strzednicki J., Logika i jej rola wobec myślenia, [w:] Logiczne podstawy rozumowań, cz. 2, red. L. Kostro, J. Przybyłowski, Gdańsk 1997.

[43] Szczepański J., Elementarne pojęcie socjologii, Warszawa 1970.

[44] Topolski J., Jak się pisze i rozumie historię: tajemnice narracji historycznej, Warszawa 1996.

[45] Uliński T., Opis i wyjaśnianie: zarys problematyki, [w:] Elementy teorii polityki, red. K. Opałek, Warszawa 1989.

[46] Zieliński H., O potrzebie i trudnościach badania dziejów polskiej myśli politycznej, [w:] Polska myśl polityczna XIX i XX wieku, t. 1: Polska i jej sąsiedzi, red. H. Zieliński, Wrocław-Warszawa-Kraków-Gdańsk 1975.

[47] Zybertowicz A., Kategorie do badania polskiej myśli politycznej. (Rozważania wstępne), [w:] Studia z dziejów polskiej myśli politycznej, t. 2: Polska myśl polityczna $w$ dzielnicy pruskiej $w$ XIX wieku, red. S. Kalembka, Toruń 1990.

\section{CONSEQUENCES OF DEFINING POLITICAL THOUGHT FOR QUESTIONNAIRE OF THE POLITICAL SCIENCE RESEARCH}

The publication discusses the consequences of modernizing the definition of political thought for questionnaire of the political science research. In the eighties and nineties of the twentieth century political thought was defined as a reflection of politics, while the development the identity of political science has forced the use of the category of political reality in the process of defining. There was a link between the concept of political thought with the terms politicality and politicization. The analysis made in the article shows that fundamental changes in the definition of political thought, which took place in the first decade of the twenty-first century, generating the need for the appointment of new research tasks for political scientists - researchers of political thought. New challenges (duties) appeared for political scientists for three cognitive needs. These are: 1) studying the views of political subjects on the politicality and policy; 2) broadening the base of sources of traces of political thought; 3 ) the standardization of political science research carried out in the sub-discipline. The article pointed out the two types of sources in the study of political thought - the evidences and signs of political thought and proposes three research questionnaires, joined together: universal, historical and special.

Keywords: political thought, methodology of political science, theory of politics.

DOI:10.7862/rz.2015.hss.11

Przesłano do redakcji: listopad 2014

Przyjęto do druku: maj 2015 